\title{
Pogranicze fotografii - znaczenie stopklatki w dziele filmowym
}

Stopklatka jest specyficznym elementem wyrazu w kinematografii. Stoi bowiem Sna pograniczu starej formy fotograficznego zatrzymania obrazu w kadrze i malarskiej ramie dzieła sztuki oraz jest wypadkową filmowanej, ruchomej rzeczywistości. Paradoksalnie jednak dzięki tej wewnętrznej sprzeczności posiada możliwość odmiennej wymowy stylistycznej i metaforycznej. Zatrzymuje chwilę, nie będąc zdjęciem. Jednocześnie jest wpleciona w następstwo czasowe, ale nie jest ruchomym ujęciem filmowym. Zamierzeniem poniższej analizy jest ustalenie definicji stopklatki i prześledzenie sposobów jej wykorzystania w kinematografii.

\section{Stopklatka - próba definicji}

W gramatyce języka filmowego, opisującego zagadnienia elementów tworzenia dzieła kinematograficznego, stopklatka nie jest zjawiskiem często podejmowanych rozważań. Wydaje się być przypisywana bardziej technicznej stronie montażu niż stylistyce opowiadania filmowego ${ }^{1}$. Z realizacyjnej strony tworzenia obrazu audiowizualnego stopklatka jest to obraz filmowy zatrzymywany na ekranie w czasie projekcji. Jest to zatem zabieg montażowy, który powstaje podczas pracy nad filmem, ale także decyzja odbiorcy, który zatrzymuje film (serial, program telewizyjny, teledysk) w różnorodnych celach. Stopklatkę można więc odczytywać jako fragment filmu, obrazu ruchomego, który został celowo

* Dr Joanna Sosnowska - Instytyt Dziennikarstwa i Komunikacji Społecznej, Katolicki Uniwersytet Lubelski; e-mail: joannus@autograf.pl

${ }^{1}$ Por. zagadnienia gramatyki języka filmowego można odnaleźć w opracowaniach ogólnych, m.in.: Daniel Arjon, Gramatyka języka filmowego, tłum. Adolf Forbet, Warszawa 2008, Jerzy Płażewski, Język filmu, Warszawa 2008 
zatrzymany podczas projekcji, często w konkretnym celu artystycznym. Cele te wyznaczone są przez styl filmowego opowiadania, wyrażony w gatunku dzieła filmowego, wykorzystanej muzyki czy sposobu operatorskiego fotografowania. Stopklatka znana jest jako zatrzymany kadr filmowy odczytywany powszechnie jako zdjęcie, a ściślej określając jako fotografia. Często bowiem ma charakter portretu zdjęciowego i postawione obok autentycznych zdjęć portretowych nie ukazuje widocznych różnic.

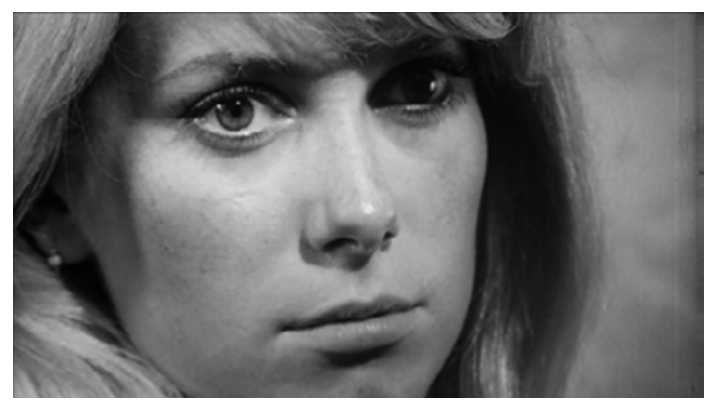

Zdj. 1.: Stopklatka z „Wstrętu” reż. R. Polański (1965)

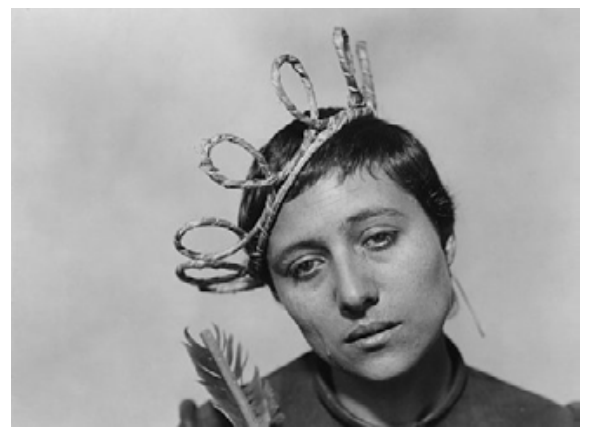

Zdj. 3.: Stopklatka z „Męczeństwa Joanny d'Arc" reż. C. T. Dreyer (1928)

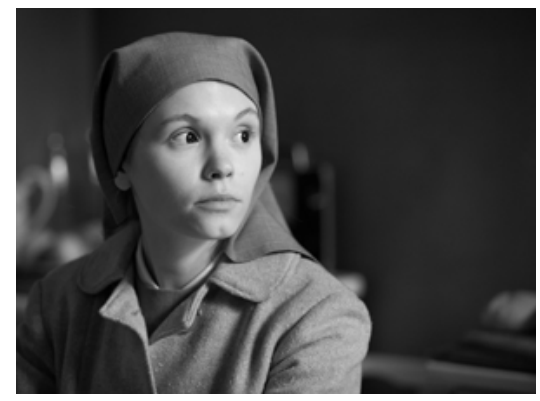

Zdj. 2.: Stopklatka z „Idy” reż. P. Pawlikowski (2013)

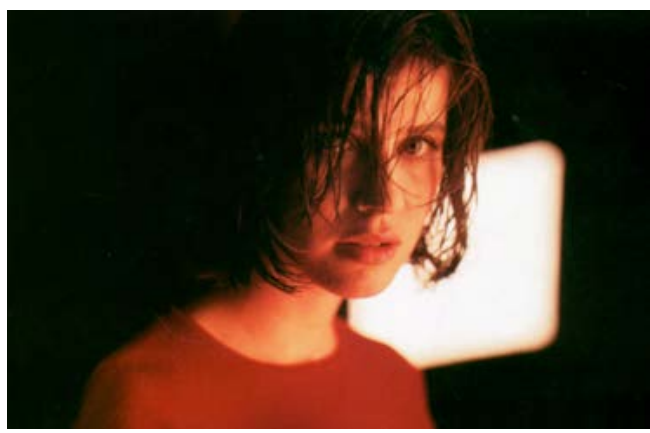

Zdj. 4.: Stopklatka z „Czerwonego” reż. K. Kieślowski

Stopklatka może być również odczytywana jako zdjęcie reportażowe. Fragment akcji filmowej zatrzymany na ekranie powoduje, że obraz staje się wycinkiem pokazywanej rzeczywistości. Reporterski świat fotografii opiera się na autentycznych wydarzeniach i postaciach. Filmowe ujęcie rzeczywistości często pokazuje jedynie wyobrażenie rzeczywistości lub twórcze odtworzenie dawnych wydarzeń. Można zatem odnaleźć stopklatkowe zdjęcia wojenne, społeczne czy historyczne. 


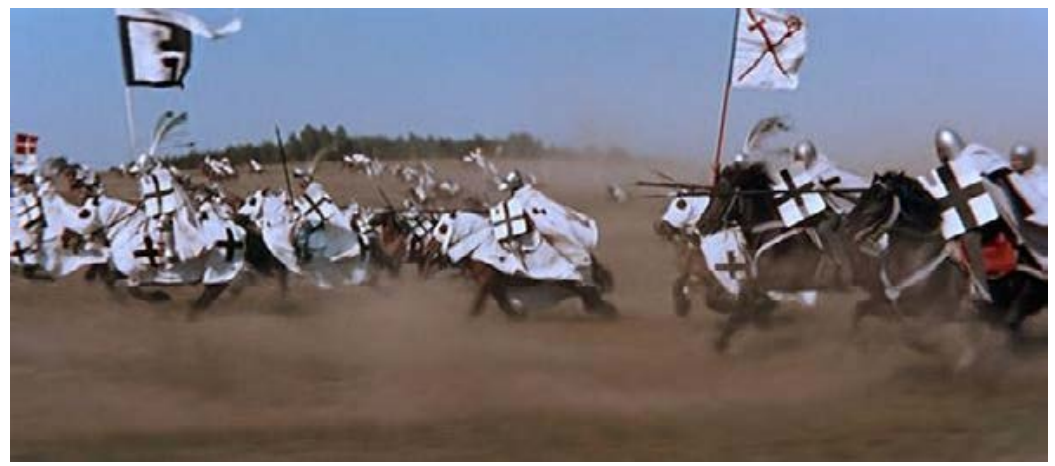

Zdj. 5.: Stopklatka z „Krzyżaków” reż. A. Ford (1960)

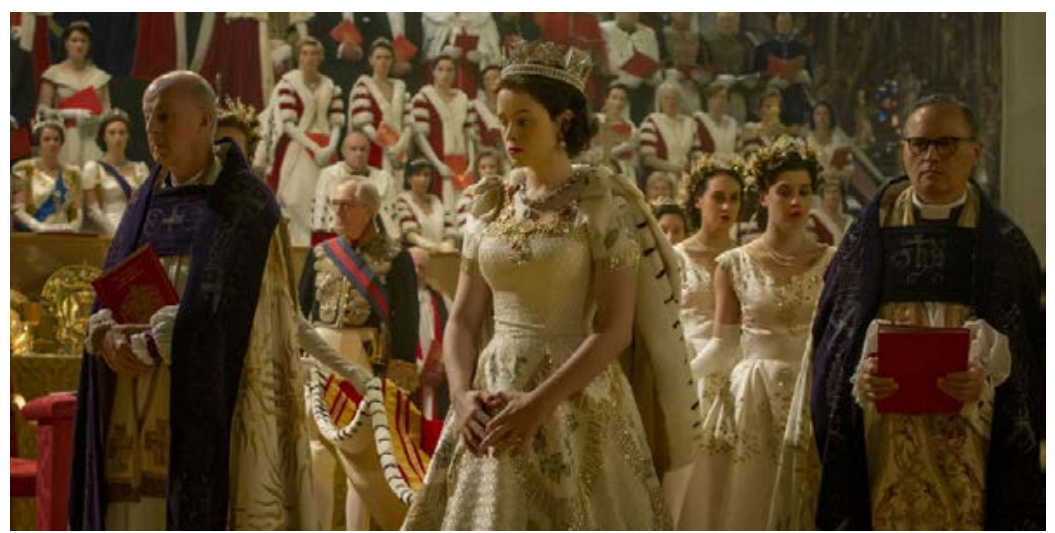

Zdj. 6.: Stopklatka z serialu „The Crown” reż. P. Morgan (2016)

\section{Stopklatka jako kalka rzeczywistości}

Stopklatka, zatrzymany w kadrze obraz jest często wiernym odtworzeniem zdjęcia czy obrazu malarskiego znanego odbiorcy z innej niż filmowa rzeczywistości. Może być ona kalką wizerunku postaci lub sytuacji w formie kroniki wydarzeń (ukrytych w narracji filmowej):

a) kalka wizerunku postaci - twórcy filmowi podkreślają, jak duże znaczenie ma fotografia, obraz malarski w kreacji postaci filmowej. Na ich podstawie bowiem można nie tylko inspirować się w tworzeniu postaci, ale także wiernie odtworzyć danego bohatera, ożywić go w narracji filmowej. Widać to dokładnie, kiedy zdjęcie staje się inspiracją dokumentalną do filmu faktu, biografii filmowej czy dzieła historycznego. Odtwarzane są osoby z ich charakterystyką wizualną, strojem czy fryzurą, ale również szuka się ich cech charakteru dzięki mimice, spojrzeniu czy pozie ciała 
uwiecznionej na zdjęciu lub obrazie. Budowana w ten sposób postać na ekranie staje się wiarygodna dla widza i koresponduje $\mathrm{z}$ jego obrazem osoby znanej z innych (statycznych) przekazów wizualnych. Celowe zatrzymanie kadru filmowego $\mathrm{z}$ daną postacią pozwala na precyzyjne dopasowanie wizerunku $\mathrm{z}$ filmową kreacją.

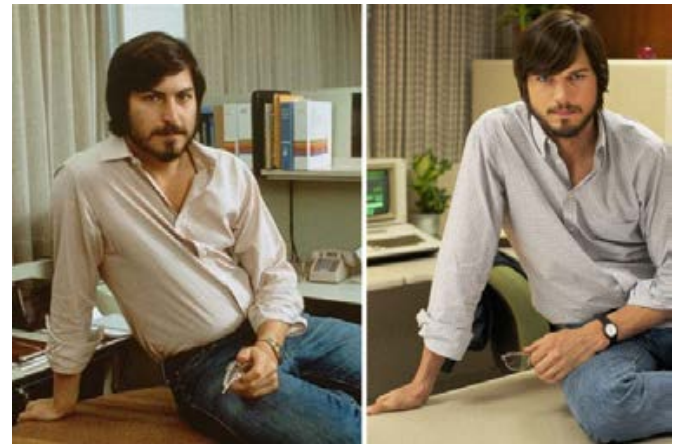

Zdj.7: Fotografia Steva Jobsa i stopklatka z filmu „Jobs”

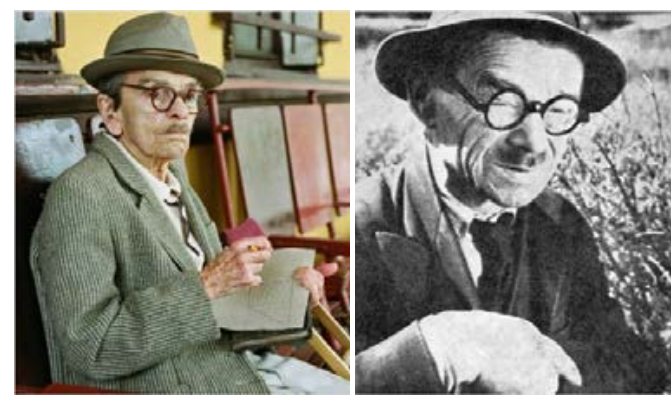

Zdj. 9: zdjecie Nikofora i stopklatka z filmu „Mój Nikofor”
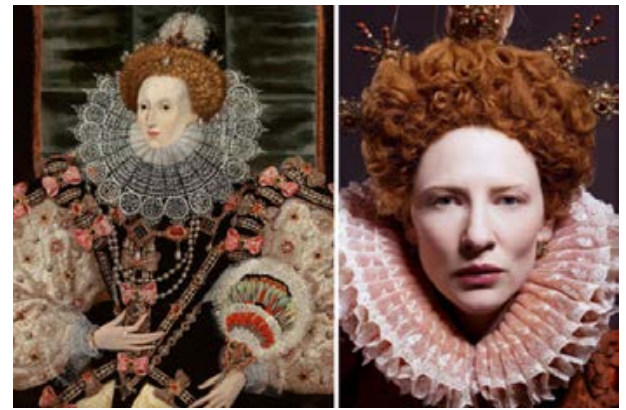

Zdj. 11: Portret Elżbiety I i stopklataka z filmu „Elizabeth”
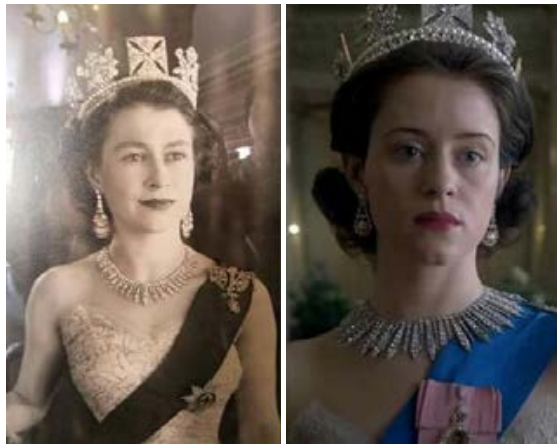

Zdj.8: Fotografia Elżbiety II i stopklatka z filmu „The Crown”

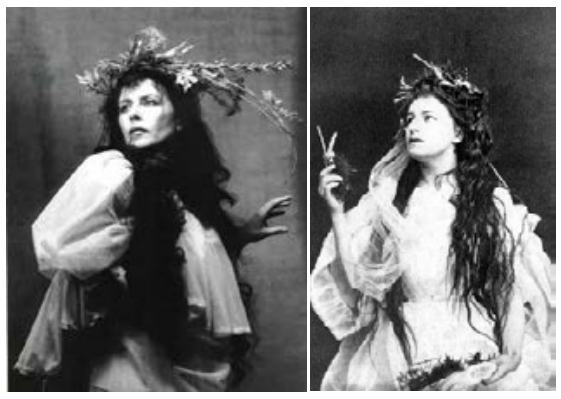

Zdj. 10.: zdjęcie Heleny Modrzejewskie i stopkaltka z filmu „Helena Modrzejewska”

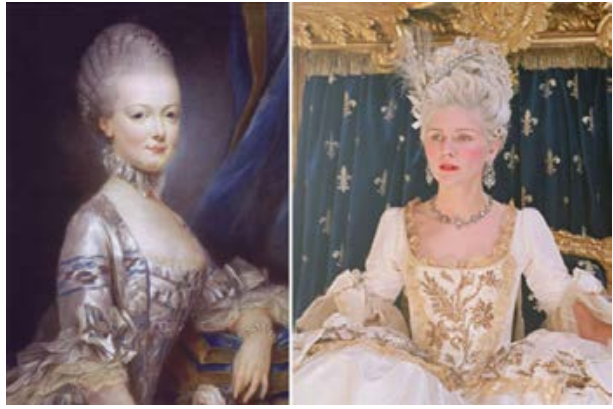

Zdj. 12: Portret Marii Antoniny i stopklatka $\mathrm{z}$ filmu „Marie Antoinette” 
Ewidentne, wręcz kopistyczne podobieństwo stopklatowych wizerunków postaci filmowych do ich zdjęć czy portretów malarskich staje się wyznacznikiem kunsztu charakteryzacji filmowej, precyzji kostiumologów i trafności doboru aktora ${ }^{2}$. Widz zatem otrzymuje postać - obraz, postać - portret, który tylko utrwala jego wiedzę wizualną o filmowanej postaci. Kalkując autentyczne postaci i ich portretowe wizerunki umacnia się poczucie ekranowej prawdy, co przy filmach biograficznych czy historycznych ma niebagatelne znaczenie. Jednocześnie może to powodować kolejny głos w dyskusji czy film może być traktowany jako źródło wiedzy historycznej

b) Stopklatka ukryta w narracji - pojawiają się znane w kulturze sytuacje znane z relacji reporterskich, telewizyjnych, fotograficznych, które funkcjonują w świadomości widzów i są odczytywane jako ukryte stopklatki z odtwarzanej $\mathrm{w}$ filmie rzeczywistości. Nie tylko możemy uchwycić poprzez stopklatkę portret postaci, ale wydarzenie, w którym uczestniczył. Zestawione poniżej przykłady fotografii i filmowych stopklatek doskonale ukazują, jak złudne wydaje się poczucie prawdziwości przedstawianych na nich wydarzeń. Jednolitość stylistyczna fotografii i stopklatek powoduje, że filmowe kadr mogłyby zastąpić autentyczne fotografie prawdziwych wydarzeń.

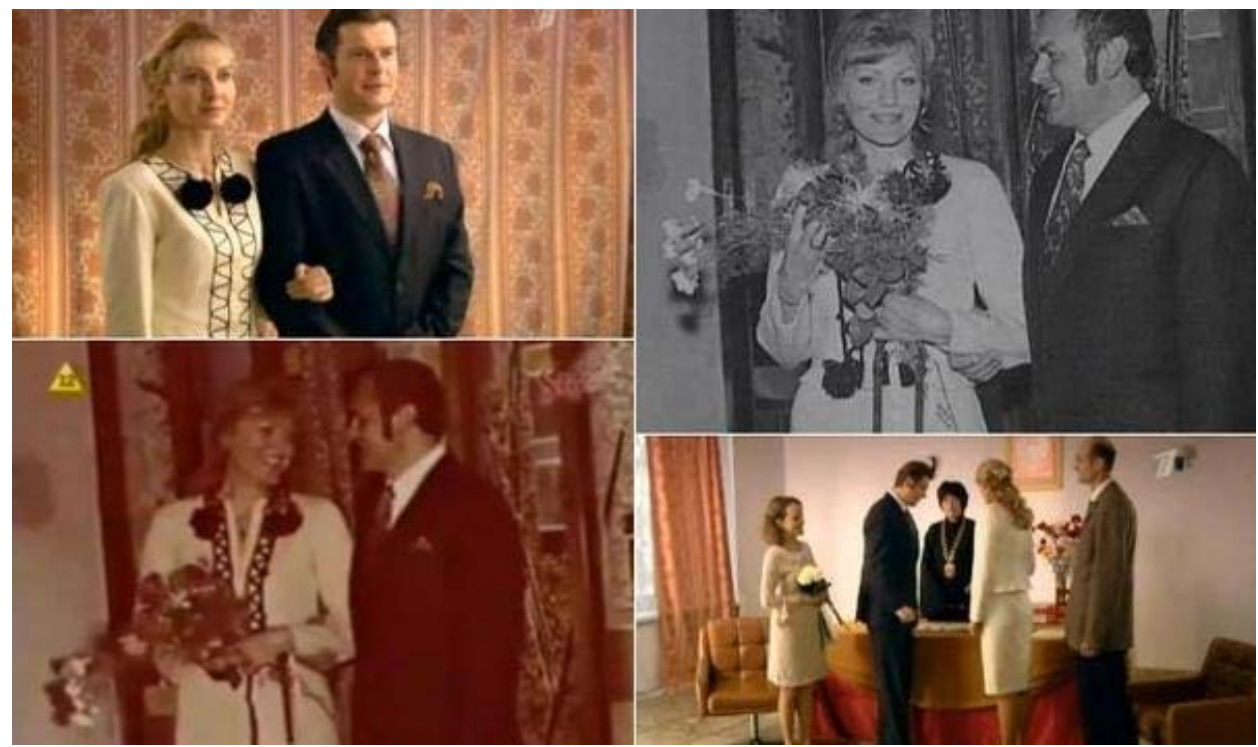

Zdj. 13: Zdjęcia ze ślubu Anny German i stopklatki z serialu „Anna German”

${ }_{2}^{2}$ Reiss Smith, The cast of The Crown vs the real Royal Family, http://www.express.co.uk/showbiz/ tv-radio/742509/the-crown-netflix, dostęp 16.10.2017

${ }_{3}^{3}$ Zagadnienia filmu jako źródła historycznego podejmują m.in.: Władimir Markowicz Magidow, Film jako źródło historyczne: problemy pojmowania i wykorzystania filmu jako tekstu, „Sensus Historiae” 2004, nr 1, s. 65-80, Marek Hendrykowski, Film jako źródło historyczne, Poznań 2000, 


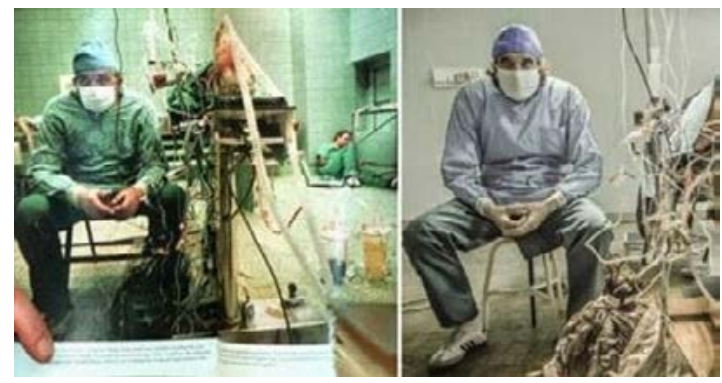

Zdj. 14: Zdjęcie Zbigniewa Religi i stopklatka z filmu „Bogowie”

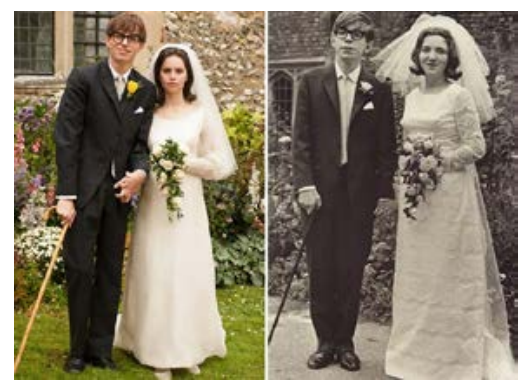

Zdj.15 Zdjęcia ze ślubu Stephena Hawkinga stopklatka $\mathrm{z}$ filmu „Teoria wszystkiego"

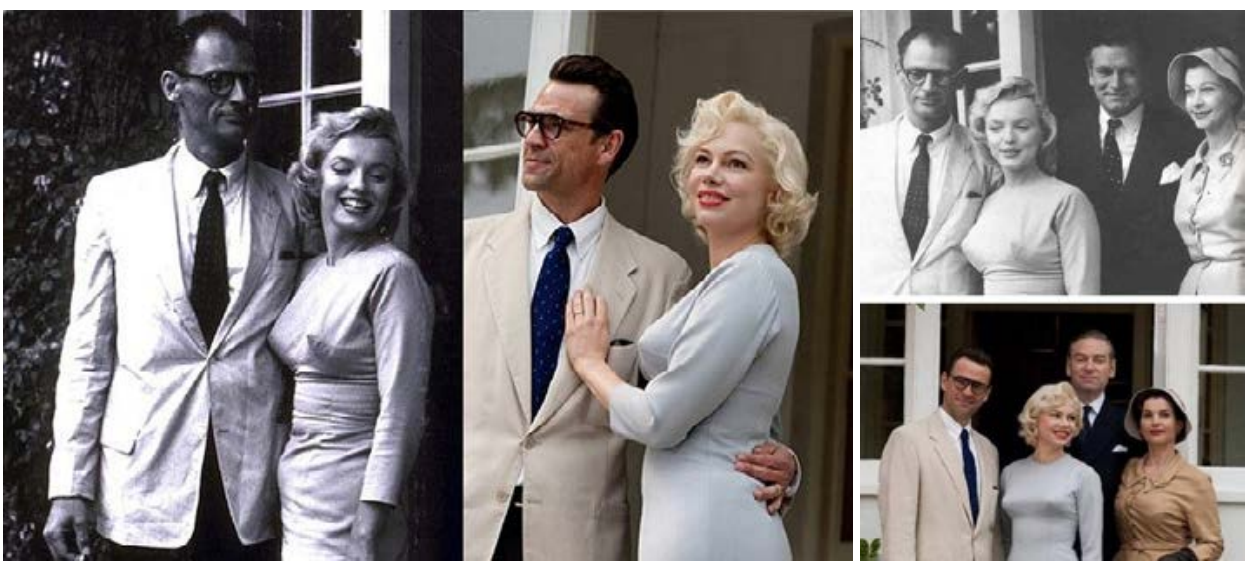

Zdj.16: Zdjęcia Marlin Monroe i stopklatka z filmu „Moje życie z Marlin”

c) stopklatka kulturowa - pojawianie się na ekranie znanych dzieł sztuki czy zabytków wydaje się rzeczą oczywistą. W tym kontekście stopklatka jest elementem kulturowej pamięci, która, w różnym stopniu świadomości, powoduje $\mathrm{u}$ widza odkrywanie tożsamości kulturowej. Widoczne jest to w inspiracjach filmowych wykorzystujących za temat swoich dzieł malarstwo ${ }^{4}$. Jednym z najbardziej malarskich twórców filmowych w Polce jest Andrzej Wajda ${ }^{5}$.

${ }^{4}$ Por.: Agnieszka Kowalska, Edward Hopper. Zawód: reżyser. Od dziś w kinach film „Shirley - wizje rzeczywistości", http://wyborcza.pl/1,75410,15658707,Edward_Hopper_Zawod_rrezyser__ Od_dzis_w_kinach_film.html, dostęp 13.10.2017

5 Por. : Dariusz Chyb, Malarstwo w filmach Andrzeja Wajdy „Wesele”, „Kino” 1988 r., nr 12, s. 24-28 oraz Dariusz Chyb, Inspiracje malarskie w filmach Andrzeja Wajdy, „Kwartalnik filmowy” 1996/1997, nr 15/16 


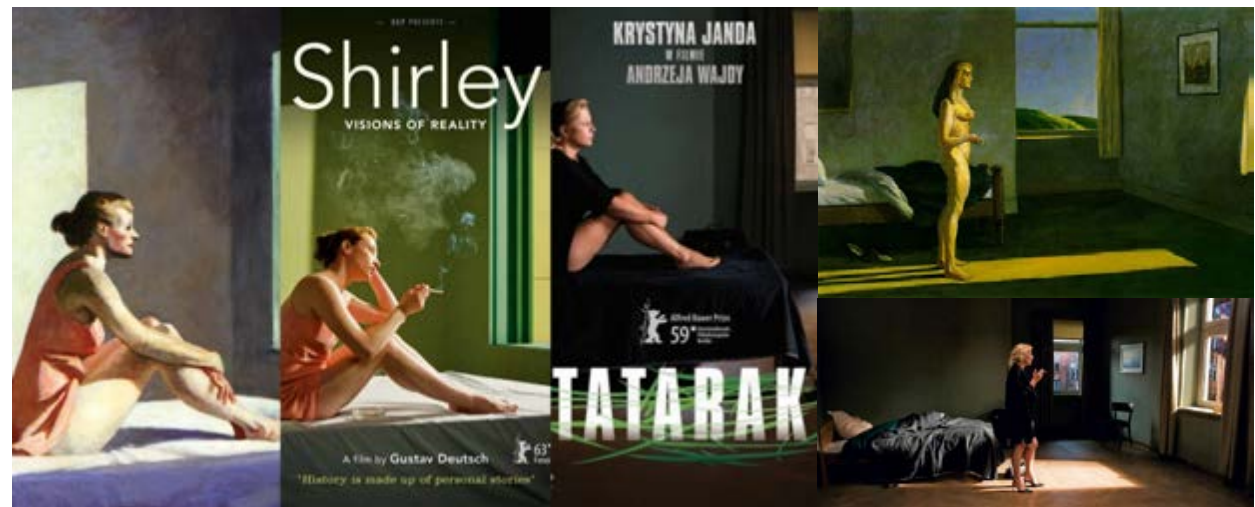

Zdj. 17: Malarstwo Edwarda Hoppera w inspiracji Andrzeja Wajdy „Tatarak” i Gustawa Deutscha „Shirley”

Te same funkcje mają wcześniej wymieniane portrety kalki. Na ekranie w jednej chwili widzimy nie tylko fragment filmu, kadr filmowy, ale obraz malarski. Często połączony z powolnym, minimalnym ruchem kamery lub kadrem statycznym, aby wprowadzić jak najbliższe ludzkiemu oku złudzenie oglądania plastycznego dzieła sztuki. Interesującym wydaje się połączenie przeciwieństw: linearności i statyczności takiego zabiegu filmowego. Z jednej strony bowiem mamy narrację ciągłą, filmową opowieść, następujące po sobie sytuacje dźwiękowe i obrazowe. Z drugiej natomiast zamrożenie chwili i stopklatkowe zatrzymanie na konkretnym, znanym ze sztuki kadrze. Dzięki temu oglądany obraz powoduje specyficzne doznania estetyczne widza, które wymykają się poza czysto filmowe czy muzealne.

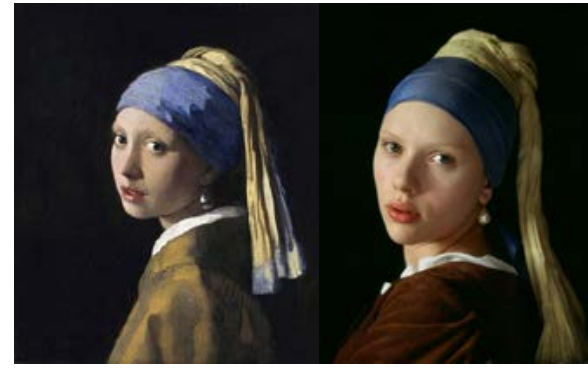

Zdj. 18: Stopklatka z „Dziewczyny z perłą” reż. P. Webbe i obraz o tym samym tytule Jana Vermeera

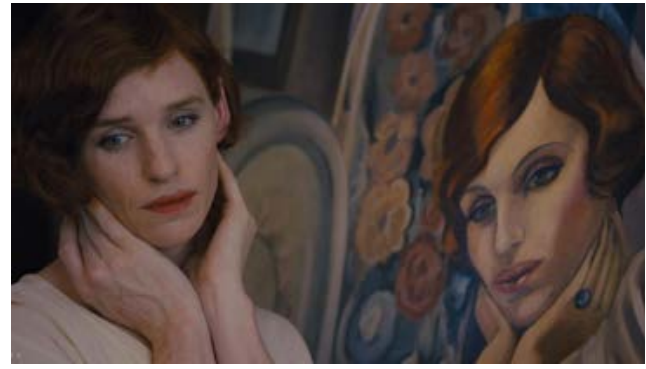

Zdj. 19: Stopklatka z „Dziewczyny z portretu” reż. T.Hooper oraz obraz Gerdy Wegener 


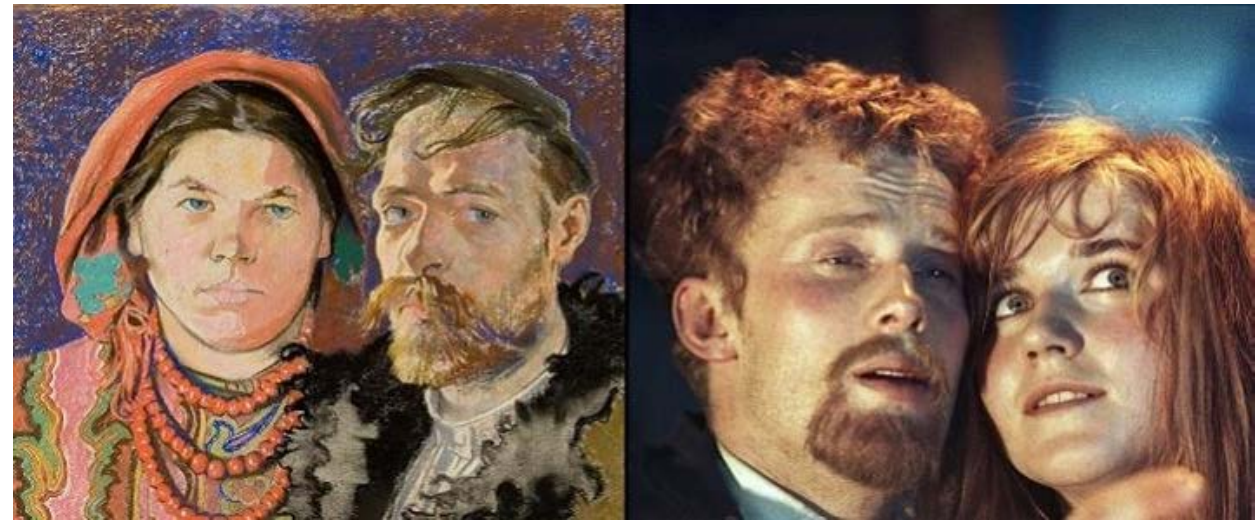

Zdj. 20: Stopklatka z „Wesela” na postawie dramatu St. Wyspiańskiego, reż. A. Wajda i obraz St. Wyspiańskiego"Portret z żoną"

\section{Stopklatka jako zabieg stylistyczny}

Stylistyczne wykorzystanie stopklatki nie występuje zbyt często, ale ma duży potencjał dramaturgiczny. Stopklatka może być specyficznym zakończeniem lub rozpoczęciem akcji, wzmacniać kontrast czy drastycznie zmienić akcję wydarzeń.

a) stopklatka jako zakończenie opowieści - wiele narracji filmowych kończy się zatrzymaniem ostatniego kadru. Dzięki temu finalizuje się filmowana opowieść i mimo braku ruchu (reakcji bohatera) wywoływany jest silny akcent emocjonalny. Takie rozwiązanie realizacyjne $\mathrm{w}$ kinie jest wykorzystywane $\mathrm{w}$ wielu przypadkach od zatrzymania akcji po portretowanie postaci bohaterów i przewidywanie ich dalszych losów. Przykładem takiego rozwiązania jest kino sportowe, którego akcja często koncentruje się na dążeniu do wygranej bohatera indywidualnego lub zbiorowego. Końcową sceną jest moment triumfu bohaterów a zabiegiem realizacyjnym zatrzymanie kadru w najbardziej emocjonującym momencie. Stopkaltka przypomina wtedy zdjęcie fotoreportera sportowego, które można ujrzeć w prasie branżowej lub na portalu internetowym. Filmowym wyróżnikiem jest muzyka, która jako klasyczny zabieg filmowy ożywia nieruchomy obraz, wywołując odpowiednie uczucia widza. 


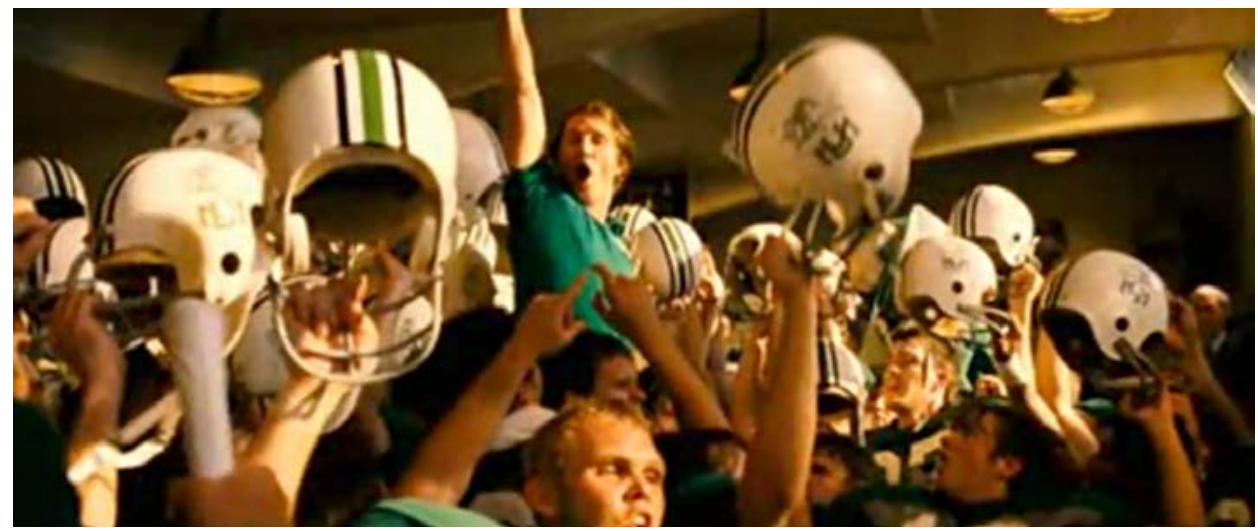

Zdj. 21: Stopklatka z filmu „Męski sport” reż. J.M. Nichol

Odmiennym typem wymowy podobnego zabiegu jest zatrzymanie kadru kończące opowieść filmową pokazujący portrety bohaterów. Dzięki temu twórca filmu ma możliwość nie zmieniając wizualnego następstwa zdarzeń, opowiedzieć w skrócie dalsze losy bohaterów. Informacja przedstawiona jest jako tekst offowy (narratora lub bohatera) lub w postaci tekstu pisanego wyświetlanego na stopklatkach.

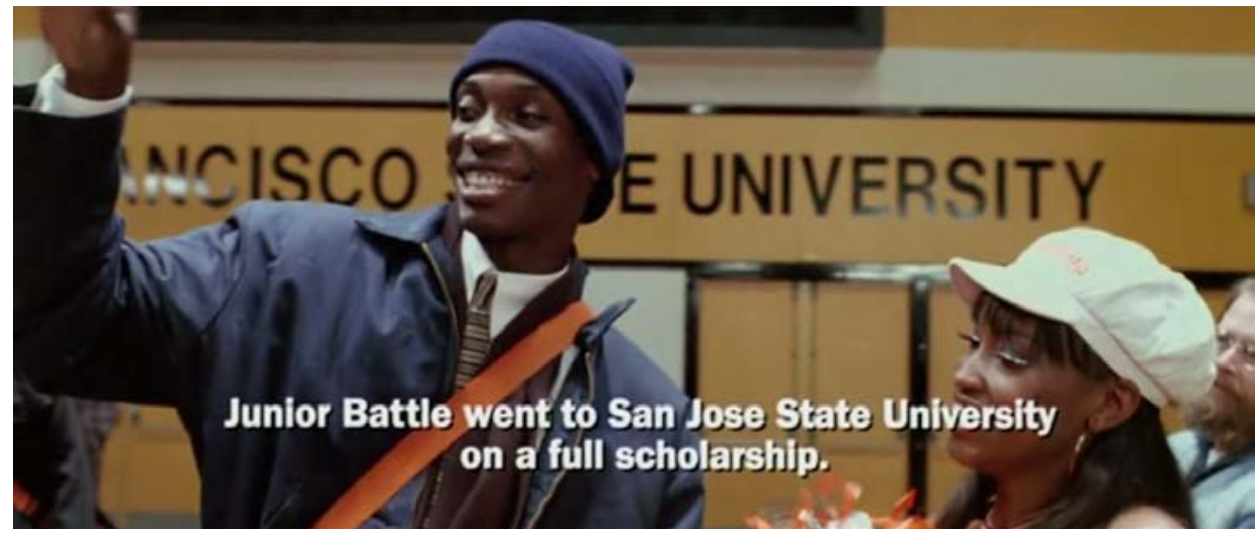

Zdj. 23: Stopklatka końcowa z filmu „Trener” reż. Thomas Carter

Zakończeniem opowieści filmowej może być też stopklatka imitująca zdjęcie pamiątkowe (portretowe), które jest pretekstem do retrospekcji narracji. $\mathrm{Na}$ nieruchomym kadrze widz przygląda się głównej postaci filmu, po czym następuje seria krótkich chronologicznych dynamicznych ujęć doprowadzających bohatera do początku filmowej opowieści. 


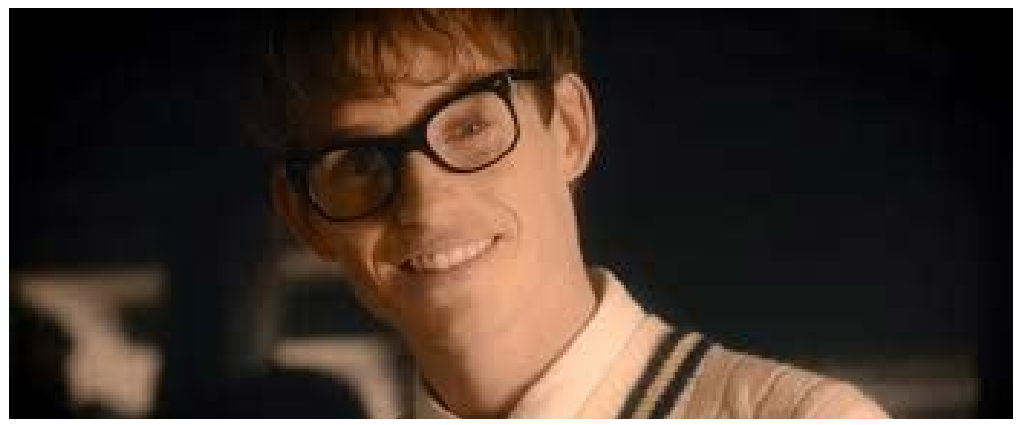

Zdj. 24: Stopklatka z „Teorii wszystkiego” reż. James Marsh

b) stopklatka jako moment zwrotu akcji - stopklatka bywa również elementem dramaturgii narracji filmowej. Nie tylko zawiesza czy kończy akcję i portretuje postaci, ale jest wykorzystywany do zmiany akcji i odwrócenia opowieści filmowej. Ciekawą kumulacją takich zabiegów jest film „Biegnij Lola, biegnij” w reżyserii Toma Tykwera. Konwencja scenariusza polega na wielokrotnym opowiadaniu tego samego wydarzenia z odmiennym zakończeniem. Każda kolejna próba pokazania historii bohaterów zaczyna się od stopkaltki, zatrzymania akcji i rozpoczęcia nowej wersji wydarzeń. Dodatkowo elementy stopklatki są wykorzystane do ukazania upływu czasu i pokazania dalszej historii bohaterów poprzez kilka stopklatek kolejnych ujęć z życia bohatera.
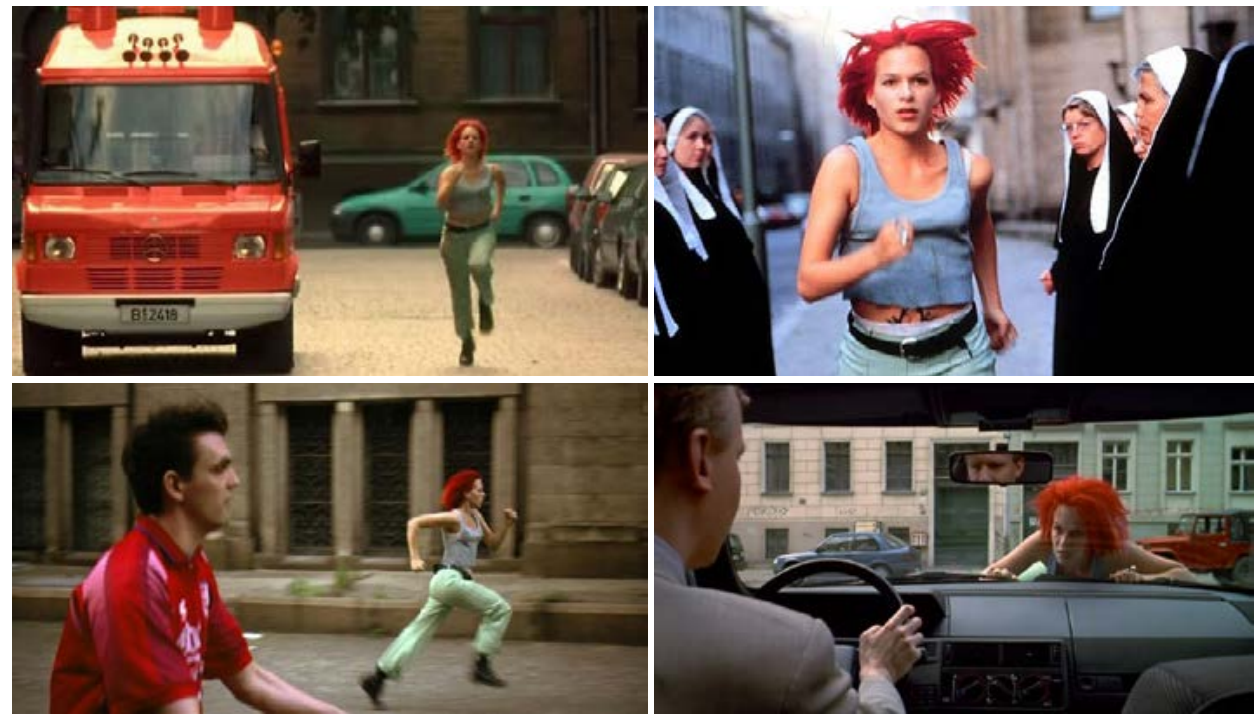

Zdj. 25: Stopklatki z „Biegnij Lola, biegnij” reż. T. Tykwer 
c) stopklataka w perspektywie czasu i akcji - definiowanie stopklatki niesie ze sobą naczelną kategorię określającą ten zabieg, a mianowicie czas. Temporalność akcji filmowej jest nie tylko wyznaczana przez ruch, przyspieszenie lub zwolnienie narracji ${ }^{6}$, ale również, w sposób specyficznie dramatyczny, dzięki zatrzymaniu akcji. Stopklatka mieści zatem w sobie silny środek zarządzania czasem. Powoduje bowiem jedność zatrzymania czasu i akcji. Nie tylko blokuje dalszy przebieg filmowanej sytuacji, utrzymanie uwagi widza, ale także może ten czas i akcję zmienić. Zatrzymanie czasu w kinematografii jest zabiegiem częstym, ale równie często unikającym w tym celu stopklatki. Twórcy filmowi wielokrotnie zatrzymują czas poprzez montaż równoległy, przeskakując z jednej linii narracyjnej do drugiej, stopując dla widza śledzoną akcję i zmuszając do czekania na jej kolejną odsłonę ${ }^{7}$. Stopklatka jest współcześnie wykorzystywana do zatrzymania czasu w sposób klasyczny, poprzez zatrzymanie kadru i rozpoczęcie innej akcji lub zakończenie filmu. Jest również wynikiem rozwoju technologicznego kinematografii i może być zamrożeniem kadru (unieruchomieniem żywych i poruszających się obiektów) przy równoczesnym płynnym ruchu pozornej kamery. Daje to efekt subiektu kamerowego czyli perspektywy patrzenia zdystansowanego narratora lub alterego bohatera.

d) stopklatka jako kontrast - stopklatka może mieć funkcję ukazania kontrastu tempa życia bohaterów, sensu życia. Może również na poziomie prostych zabiegów filmowych wzmacniać efekty dramaturgiczne poprzez kontrast wizualno-dźwiękowy. Asynchronizm warstwy fonii i wizji, poprzez równoległe prowadzenie dwóch osobnych ciągów montażowych, powoduje wyprzedzenie akcji, mimo nieruchomego obrazu poprzedniej sytuacji. Na ekranie obserwujemy ostatni kadr filmowanej sytuacji, słyszymy już natomiast początek kolejnej. Asynchronizm daje również wrażenie przeciwstawienia ukazywanej rzeczywistości poprzez zamrożenie wizji a pozostawienie dźwięków oglądanej przed chwilą sytuacji, np. śmiechu czy płaczu. Podobny zabieg może mieć również wymowę wspomnienia lub powtarzającego się motywu opowieści. Kontrast fonii i wizji może również uruchamiać wyobraźnię widza poprzez foniczną przestrzeń pozakadrową. Twórca sugeruje dzięki temu rzeczywistość rozpościerającą się wokół tej, którą fizycznie widzi odbiorca. Symulataniczość i niesymultaniczność obrazowo-dźwiękowa wykorzystywane są również często jako zabiegi wpływające na zarządzanie czasem narracji filmu.

\footnotetext{
${ }^{6}$ Por. Jerzy Płażewski, Język filmu, Warszawa 2008, s. 98-120

7 Por. Alicja Helman, Czas filmowy, w: Stownik filmu, red. R. Syksa, Kraków 2010, s.17.

${ }^{8}$ Por. David Bordwell, Kristin Thompson, Sztuka filmowa, Tłum. B. Rosińska, Warszawa 2010
} 

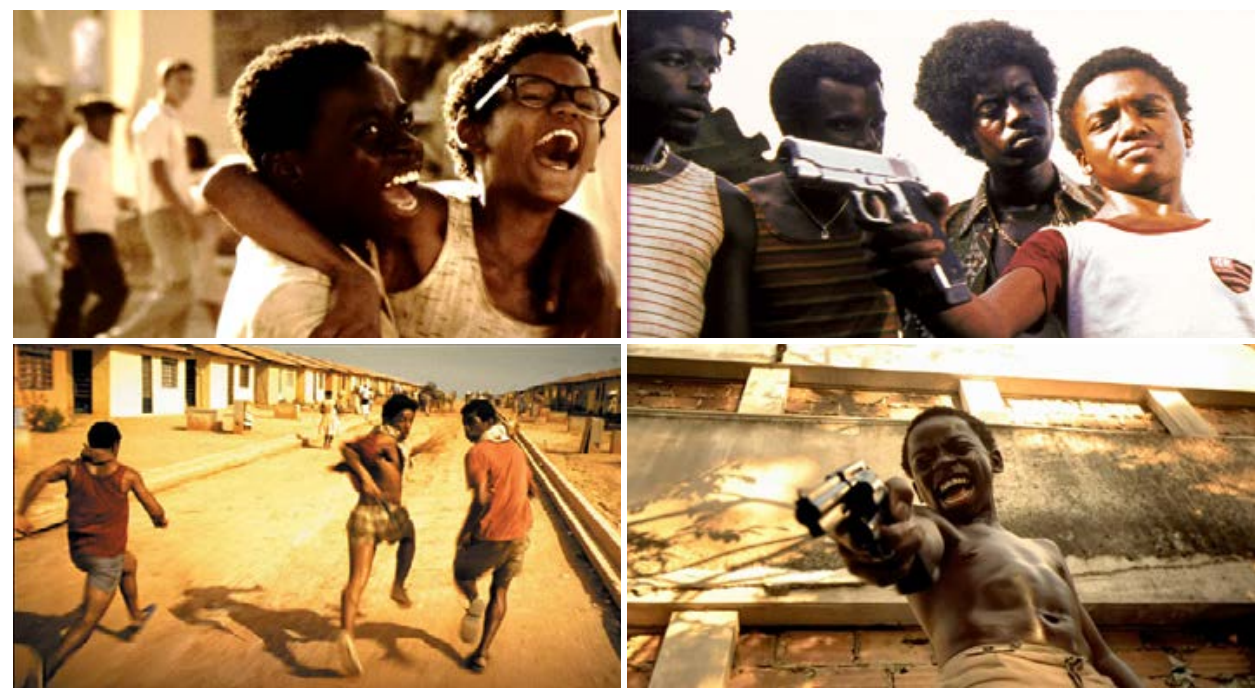

Zdj. 22: Stopklatki z filmu „Miasto Boga” w funkcji asynchronii wizualno-dźwiękowej

e) funkcja satyryczna stopklatki - jak zauważa Jerzy Płażewski, „zatrzymanie ruchu, wywołuje (...) wrażenie groteskowe, sprzeczne czasem z intencją samego twórcy"9. Naturalny ruch narracji filmowej, przerwany przez uchwycenie określonej sytuacji lub portretu bohatera, może wzmacniać sytuację, którą autor chce wyeksponować. W filmie dokumentalnym „Berlin” archiwalny cytat filmowy z podskakującym Hitlerem, cieszącym się z porażki wroga, został zatrzymany. Dramatyzm sytuacji ukazujący groteskowe ruchy Hitlera poprzez stopklatkę ukazał niedwuznaczny efekt satyryczny.

\section{Animacja poklatkowa}

Specyficzna forma wykorzystania nieruchomych kadrów ${ }^{10}$, to najprostsza definicja animacji poklatkowej. Filmy animowane, tworzone techniką poklatkową zdjęć, mogą być bardziej przypisane fotografii niż stopklatce filmowej. Uznając jednak iż, stopkaltka może być często zamiennikiem fotografii (jak wskazane zostało powyżej), sposób tworzenia ruchu poklatkowego może być identyczny. „Użycie fotografii poklatkowej musi być widocznym i znaczącym zabiegiem stylistycznym, nigdy zaś środkiem mającym na celu stworzenie iluzji rzeczy-

9 Jerzy Płażewski, Język filmu, Warszawa 2008, s. 102

${ }^{10}$ Por.: Paweł Sitkiewicz, Małe Wielkie Kino, Gdańsk 2009, Christine France, Sztuka animacji. Sztuka animacji. Od ołówka do piksela. Historia filmu animowanego, tłum. A. Kołodyński, E. Romkowska, Warszawa 2006 
wistości"11. Animacja poklatkowa wykorzystywana jest do produkcji filmów przyrodniczych, edukacyjnych pokazując etapy zmiany określonej rzeczywistości w dużej kondensacji, ściskając niejako przepasły czas do kilku chwil na ekranie. Jednocześnie jednoznacznie przypisana jest do bajek, tworzonych techniką kukiełkową, wycinankową czy plastelinową. Podobne zabiegi widać $\mathrm{w}$ filmie eksperymentalnym czy reklamowym.

\section{Znaczenie stopklatki}

Fotografia była rewolucją, która pozwoliła zatrzymać chwilę prawdziwych wydarzeń i osób. Wykroczyła poza rysunek, malarstwo. Nie tylko kopiowała świat realny, ale dawała złudzenie jego uchwycenia ${ }^{12}$. Nadal jednak nie odwzorowywała następstwa czasu, emocji ukrytych w ruchu czy głosie fotografowanych osób. Kolejną rewolucją stał się film. Film unika braku ruchu. Jest on bowiem esencją kinematografii. To ruch odróżnia film od obrazu malarskiego, fotografii czy rzeźby. Łączy wiele komponentów wizualnych i dźwiękowych, aby wprawiać je w ruch, odtwarzać obserwowaną przez nas rzeczywistość. Narodziny filmu, mimo braku mobilności kamery, były triumfem ruchu na ekranie. Fascynacja rejestracją ruchu na taśmie filmowej spowodowała pierwotny kierunek rozwoju kinematografii. Królowały sceny pościgów, ucieczek, komediowych gagów $i$ tańca ${ }^{13}$. Tendencje do zwolnień czy zatrzymania kadru narodziły się później i ukazały bardziej dramatyczne oblicze kina - portretowanie postaci, monolog wewnętrzny, impresje filmowe. Sztuka montażu ukazała, jak ciekawym elementem filmowego języka jest stopklatka. W prostym zabiegu zatrzymania płynącej na ekranie rzeczywistości pojawia się zapamiętana chwila, zatrzymanie czasu, kontrast emocjonalny, podsumowanie akcji czy stopniowanie napięcia. Twórcy filmowi wykorzystują ją do budowania groteski, tworzenia zdjęcia-dokumentu lub kontrapunktu. Zastosowanie stopklatki ma też znaczenie dydaktyczne, w kinie edukacyjnym i popularnonaukowym, kiedy pozwala na specyficzną koncentrację uwagi przynależną jedynie zdjęciu lub obrazowi. Dzięki stopklatce zamrażana jest rzeczywistość, a twórca filmowy buduje niepowtarzaną chwilę niemożliwą, w której widz może spojrzeć na ekranowy świat $\mathrm{z}$ dystansu, a jednocześnie najbliżej, jak to tylko możliwe. Asynchronizm fonii i wizji, daje interesujące możliwości pobu-

${ }_{11}$ Paweł Sitkiewicz, Małe Wielkie Kino, Gdańsk 2009, s. 33

${ }_{12}$ Por.: Agata Ciastoń, Fotografia w filmie - spotkanie mediów, w: Miejsce fotografii w badaniach humanistycznych, red. M. Ziętkiewicz, M. Biernacka, 2016, s. 255-275, D. Campany, Photogaphy and Cinema, London 2008

${ }_{13}$ Por.: David Bordwell, Kristin Thompson, Film History An Introduction. New York 2003, David A Cook, A History of Narrative Film, New York 1990, Barry Salt, Film Style and Technology: History and Analysis, Starword 1992 
dzania wyobraźni, wywołując u widza obraz, którego nie widzi lub zaprzeczając temu, który jest zatrzymany. Stopklatka, w izolacji, wydaje się mało interesująca. Cofa całą kinematografię do czasów fotografii. Przez filmowców wykorzystywana jest rzadko, ustępując miejsca zabiegom bardziej dynamicznym, a współcześnie animacji komputerowej. Wydaje się jednak, że zawiera w sobie wiele elementów stylistycznych, które w unikatowy sposób mogą wzmocnić filmowaną opowieść.

\section{Bibliografia:}

Płażewski J., Język filmu, Warszawa 2008.

Markowicz Magidow Wł., Film jako źródło historyczne: problemy pojmowania i wykorzystania filmu jako tekstu, "Sensus Historiae" 2004, nr 1, s. 65-80.

Hendrykowski M., Film jako źródło historyczne, Poznań 2000.

Arjon D., Gramatyka języka filmowego, tłum. Adolf Forbet, Warszawa 2008.

Sitkiewicz P.: Małe Wielkie Kino, Gdańsk 2009.

France Ch., Sztuka animacji. Sztuka animacji. Od ołówka do piksela. Historia filmu animowanego, tłum. A. Kołodyński, E. Romkowska, Warszawa 2006.

Block B., Opowiadanie obrazem. Tworzenie wizualnej struktury w filmie, telewizji i mediach cyfrowych, Wydawnictwo Wojciech Marzec, Warszawa 2010.

Bordwell D., Thompson K., Sztuka filmowa, Tłum. B. Rosińska, Warszawa 2010.

Helman A., Czas filmowy, w: Słownik filmu, red. R. Syksa, Kraków 2010.

Kowalska A., Edward Hopper. Zawód: reżyser. Od dziś w kinach film „Shirley- wizje rzeczywistości", http:// wyborcza.pl/1,75410,15658707,Edward_Hopper_ZZawod__rezyser__Od_dzis_w_kinach_film. html, dostęp 13.10.2017.

Chyb D., Malarstwo w filmach Andrzeja Wajdy "Wesele", "Kino" 1988 r., nr 12, s. 24-28.

Chyb D., Inspiracje malarskie w filmach Andrzeja Wajdy, "Kwartalnik filmowy” 1996/1997, nr 15/16.

David Bordwell D., Kristin Thompson, Film History An Introduction. New York 2003.

Cook David A., A History of Narrative Film,New York 1990.

Salt B., Film Style and Technology: History and Analysis, Starword 1992.

Smith R., The cast of The Crown vs the real Royal Family, http://www.express.co.uk/showbiz/tv-radio/742509/the-crown-netflix, dostęp 16.10.2017.

Ciastoń A., Fotografia w filmie - spotkanie mediów, w: Miejsce fotografii w badaniach humanistycznych, red. M. Ziętkiewicz, M. Biernacka, 2016, s. 255-275.

Campany D., Photogaphy and Cinema, London 2008.

\section{Streszczenie:}

Stopklatka jest fragmentem filmu, obrazu ruchomego, który został (celowo) zatrzymany podczas projekcji, najczęściej na krótką chwilę, w konkretnym celu artystycznym. Stopklatka jest specyficznym elementem wyrazu w kinematografii. Stoi bowiem na pograniczu starej formy fotograficznego zatrzymania obrazu w kadrze i malarskiej ramie dzieła sztuki oraz jest wypadkową filmowanej, ruchomej rzeczywistości. Zamierzeniem artykułu jest ustalenie definicji stopklatki i prześledzenie sposobów jej wykorzystania w kinematografii.

Słowa kluczowe: stopklatka, film, fotografia, kinematografia, montaż filmowy. 


\section{Borderland of the photograph - meaning freeze frame in the movie}

\section{Summary:}

Freeze frame is a still picture in the course of a movie or television film, made by running a series of identical frames or by stopping a reel or videotape at one desired frame. It is a peculiar element of the word in the cinematography. He is standing on the border of old form of photographic stopping the image and in the painting frame of the works of art and is a resultant of filmed, movable reality. Establishing the definition freeze frame is a purpose of the article and of portraying ways for it of using in the cinematography.

Keywords: freeze frame, movie, photography, cinematography, film editing. 